\title{
Surgical treatment of superior bullous rhegmatogenous retinal detachments
}

\author{
M R STANFORD AND A H CHIGNELL \\ From the Ophthalmic Department, St Thomas's Hospital, London SE1 7EH
}

SUMMARY The results in 90 patients with superior bullous rhegmatogenous detachments operated on over a period of 10 years are presented. In only $70 \%$ of cases treated by scleral buckling, with or without drainage of subretinal fluid, was retinal reattachment achieved with a single operation. More recently the treatment of patients by external drainage, air injection into the vitreous cavity, and subsequent buckling has improved the success rate to $96 \%$. It is suggested that the latter method be the surgical treatment of choice in such cases.

\begin{abstract}
The use of non-drainage procedures, introduced by Custodis' and popularised by Lincoff and Kreissig, ${ }^{2}$ makes a retinal detachment repair an entirely extraocular procedure. This procedure becomes difficult when deep subretinal fluid (SRF) is present between the detached retina and the pigment epithelium. Wide separation between the retinal layers inhibits accurate localisation of retinal holes and makes the application of cryotherapy difficult to judge. These difficulties often necessitate external drainage of SRF with its attendant risks. ${ }^{3}$ The depth of SRF may be decreased either by preoperative posturing ${ }^{45}$ or by immobilisation of the globe by surgical means. ${ }^{67}$ In most cases treated by preoperative posturing such settling back does not occur, and the surgeon is then confronted with the problem of deep SRF at the time of operation. We have varied the surgical approach to these cases over the last 10 years and report our experience in the management of 90 cases.
\end{abstract}

\section{Materials and methods}

A consecutive series of 1050 patients admitted for retinal detachment surgery between 1974 and 1984 was studied. All patients had a full preoperative assessment with binocular indirect ophthalmoscopy, scleral depression, and three-mirror gonioscopy. Although this study was retrospective, at the time of examination particular attention had been paid to the depth of SRF between retinal holes and the pigment epithelium. The detachment was defined as bullous if no part of the retinal hole could be approximated to

Correspondence to Mr M R Stanford, FRCS. the underlying pigment epithelium by scleral indentation either preoperatively or at the time of operation. In all cases studied the hole(s) lay above the horizontal meridian. Details of preoperative findings, surgical technique, and postoperative course were entered on a proforma sheet for each case. Visual acuity and the anatomical state of the retina were assessed during postoperative visits; follow-up ranged from six months to eight years. Excluded from consideration were those patients in whom the detachment had been present for more than six months, in whom a giant tear or dialysis were present, or in whom there was evidence of widespread periretinal membrane formation.

\section{SURGICAL METHODS}

Over the 10 years of the study patients with bullous detachments were treated in one of three ways. In all cases scleral buckling was performed, either with a Silastic sponge as a local radial or circumferential implant, or with a silicone rubber band if encirclement was deemed necessary. Initially conventional buckling surgery with or without external drainage or subretinal fluid was performed. More recently external drainage has been combined with the intravitreal injection of air prior to cryotherapy and buckling. In this method, after external drainage of SRF, approximately $2 \mathrm{ml}$ of air was injected via the pars plana into the vitreous cavity by a freely running syringe with a 27 gauge needle. To encourage the production of a single bubble of air the eye was rotated prior to injection so that the injection site was at the uppermost part of the globe. After identification of the tip of the needle in the vitreous cavity 
the injection was begun, and it was continued (under indirect ophthalmoscopic observation) until the detached retina was seen to be approximated to the underlying pigment epithelium. The sclerotomy used for SRF drainage was then closed and cryotherapy and scleral buckling carried out. Postoperatively those patients who had had air injected were positioned in the head-down position for some days to avoid lenticular contact with the intravitreal air. ${ }^{8}$

\section{Results}

Ninety patients were found to have bullous retinal detachments as defined for inclusion in the study. Of the 90 cases 47 (52\%) had non-drainage surgery, 18 $(20 \%)$ external drainage and buckling, and $25(28 \%)$ drainage, air injection, and buckling. Although the groups are not statistically comparable, we did not notice any obvious difference between them when age, refraction, and number of retinal holes were considered (Table 1). The duration of the retinal detachments also appeared to be similar in the three main groups (Table 2). The results of the individual procedures are summarised in Table 3.

\section{NON-DRAINAGE AND BUCKLING}

Of the 47 patients treated in this way the retina reattached with one procedure in $34(72 \%)$. The reasons for failure of the initial procedure are shown in Table 4, and it may be seen that inaccurate localisation of the buckle was the cause in the majority of cases (11 of 13). One patient had an undetected retinal hole and another developed severe periretinal membranes.

EXTERNAL DRAINAGE OF SRF COMBINED WITH BUCKLING

Of the 18 patients treated in this way the retina was reattached with one procedure in $12(66 \%)$. The remaining cases all failed because of inaccurate placement of the buckle.

EXTERNAL DRAINAGE OF SRF, INTRAVITREAL AIR INJECTION, AND BUCKLING

Of the 25 patients in this group the retina failed to become reattached with one procedure in only one $(4 \%)$. and this was also associated with inaccurate localisation. This patient went on to develop preretinal membranes, and the retina remained detached at six months (Table 5). No serious complications were encountered as a consequence of intravitreal injection.

Visual acuities and the anatomical state of the retina at six months are shown in Table 5 . There is no obvious difference between the three groups in terms of visual acuity. In both cases where the retina
Table 1 Preoperative factors

\begin{tabular}{lrrr}
\hline & $\begin{array}{l}\text { Non- } \\
\text { drainage }\end{array}$ & $\begin{array}{r}\text { External } \\
\text { drainage }\end{array}$ & $\begin{array}{c}\text { Drainage } \\
\text { and air }\end{array}$ \\
\hline $\begin{array}{l}\text { Age of patients } \\
0-50\end{array}$ & $\begin{array}{rrr}6(13 \%) \\
51-70\end{array}$ & $\begin{array}{r}2(11 \%) \\
16(89 \%)\end{array}$ & $\begin{array}{r}5(20 \%) \\
20(80 \%)\end{array}$ \\
\hline $\begin{array}{l}\text { Refraction of patients } \\
\text { Emmetropic }\end{array}$ & $14(30 \%)$ & $7(39 \%)$ & $11(43 \%)$ \\
$\begin{array}{l}\text { Myopic } \\
\text { Aphakic }\end{array}$ & $25(53 \%)$ & $8(44 \%)$ & $11(43 \%)$ \\
$8(17 \%)$ & $3(17 \%)$ & $3(14 \%)$ \\
\hline $\begin{array}{l}\text { Number of holes present } \\
\text { Single }\end{array}$ & $31(66 \%)$ & $10(55 \%)$ & $10(40 \%)$ \\
Multiple & $16(34 \%)$ & $8(45 \%)$ & $15(60 \%)$ \\
\hline
\end{tabular}

Table 2 Duration of detachment

\begin{tabular}{lrrc}
\hline & $\begin{array}{l}\text { Non- } \\
\text { drainage }\end{array}$ & $\begin{array}{l}\text { External } \\
\text { drainage }\end{array}$ & $\begin{array}{l}\text { Drainage } \\
\text { and air }\end{array}$ \\
\hline Less than one week & $22(47 \%)$ & $7(39 \%)$ & $10(40 \%)$ \\
One to four weeks & $20(43 \%)$ & $8(44 \%)$ & $13(52 \%)$ \\
One to six months & $5(10 \%)$ & $3(17 \%)$ & $2(8 \%)$ \\
\hline
\end{tabular}

Table 3 Results of surgery

\begin{tabular}{llcc}
\hline & $\begin{array}{l}\text { Non- } \\
\text { drainage }\end{array}$ & $\begin{array}{l}\text { External } \\
\text { drainage }\end{array}$ & $\begin{array}{l}\text { Drainage } \\
\text { and air }\end{array}$ \\
\hline Flat with one procedure & $34(72 \%)$ & $12(66 \%)$ & $24(96 \%)$ \\
Reoperation & $13,(28 \%)$ & $6(33 \%)$ & $1(4 \%)$ \\
Total & 47 & 18 & 25 \\
\hline
\end{tabular}

Table 4 Reasons for failure of initial operation

\begin{tabular}{lcll}
\hline & $\begin{array}{l}\text { Non- } \\
\text { drainage }\end{array}$ & $\begin{array}{l}\text { External } \\
\text { drainage }\end{array}$ & $\begin{array}{l}\text { Drainage } \\
\text { and air }\end{array}$ \\
\hline Inaccurately placed indent & 11 & 6 & 1 \\
Undetected hole & 1 & - & - \\
Periretinal membranc & 1 & - & - \\
\hline
\end{tabular}

Table 5 Results at six months

\begin{tabular}{lrrr}
\hline & $\begin{array}{l}\text { Non- } \\
\text { drainage }\end{array}$ & $\begin{array}{l}\text { External } \\
\text { drainage }\end{array}$ & $\begin{array}{l}\text { Drainage } \\
\text { and air }\end{array}$ \\
\hline Visual acuity at six months & & & \\
$6 / 5$ to $6 / 18$ & $18(38 \%)$ & $6(33 \%)$ & $9(36 \%)$ \\
$6 / 24$ to CF & $21(45 \%)$ & $8(44 \%)$ & $15(60 \%)$ \\
Less than CF & $8(17 \%)$ & $4(22 \%)$ & $1(4 \%)$ \\
\hline Anatomical results & 46 & 18 & 24 \\
Flat & 1 & - & 1 \\
Detached & 47 & 18 & 25 \\
Total & & & \\
\hline
\end{tabular}

$\mathrm{CF}=$ counting fingers. 
remained detached the cause was preretinal membrane formation.

\section{Discussion}

The non-drainage procedure with its outstanding advantage of avoiding intraocular complications has been found to result in a high incidence of failure (13 out of 47 cases) when applied to superior bullous retinal detachments. This is mainly due to failure accurately to localise the buckle and thus close the retinal hole. There is also risk associated with the application of cryotherapy. If neuroepithelial whitening is used as the end point of cryotherapy, excessive freezing may occur in the presence of highly detached retinal holes. Such freezing has been implicated in postoperative complications. ${ }^{910}$ Conversely, if lesser amounts of cryotherapy are used, so that only choroidal and retinal pigment epithelial blanching is produced, not only does visualisation of the freeze become difficult through a bullous detachment, but also the lesion produced will affect only the pigment epithelium, and this may jeopardise the tensile strength of the intraretinal adhesion." To overcome these combined problems the height of the detachment must be reduced either by preoperative immobilisation of the globe or by external drainage of SRF at the time of surgery. Particular difficulties are encountered after external drainage of SRF when a highly detached retina is present. As the retina settles back, it tends to become folded. Much folding makes accurate localisation of retinal holes difficult and has resulted in a high reoperation rate in this series in cases treated in this way (six out of 18 cases). These problems may be overcome by the intravitreal injection of air prior to localisation and buckling. Originally introduced in $1911,{ }^{12}$ this procedure has been advocated by many authors. ${ }^{13-16}$ Air injection will replace detached retinas against the pigment epithelium accurately and without folds, and also counteracts the hypotony induced by drainage of large quantities of SRF. Air is relatively non-toxic, though it has been implicated in the formation of posterior subcapsular cataracts. ${ }^{8}$ The main disadvantages of air injection within the vitreous cavity are the risks of lenticular or retinal damage due to misdirection of the tip of the needle, the inadvertent formation of multiple intravitreal bubbles that obscure the retinal view, and over-filling of the eye, which in turn may result in retinal incarceration at the drainage site of SRF or closure of the central retinal artery. The injections of air into aphakic eyes, while supported by some studies, ${ }^{17}$ is not advised after an intracapsular cataract extraction, as there is a risk of air gaining access to the anterior chamber and obscuring the retinal view if such access is not prevented by an intact anterior hyaloid face.

In this study we found that conventional buckling surgery, with or without the drainage of SRF, results in an unacceptably high proportion $(31 \%)$ of patients needing a further procedure, with its attendant risks. Since we have used the technique of injecting air after drainage and before localisation, the surgical success rate has increased to $96 \%$, and we have found no evidence to suggest that the visual results are inferior by this method (Table 5). We believe that this improvement is due to the more accurate buckling of the retinal hole that this procedure allows. In superior bullous retinal detachments, if preoperative immobilisation of the eye does not achieve sufficient flattening of the detached retina to allow a non-drainage operation, then external drainage followed by intravitreal injection of air and subsequent localisation, cryotherapy, and buckling should be the method of choice.

The authors thank Mrs M Grice for secretarial assistance in preparing the manuscript.

\section{References}

1 Custodis E. Bedeutet die Plombenaufnahung auf die Sklera einen Fortschritt in der operativen Behandlung der Netzhautablosung? Ber Zusammenkunft Dtsch Ophthalmol Ges 1953;58: 102-5.

2 Lincoff $\mathrm{H}$, Kreissig I. The treatment of retinal detachment without drainage of subretinal fluid (modifications of the Custodis procedure: part VI). Ophthalmology (Rochester) 1972;76:1221-33.

3 Chignell AH, Fison LG, Davies EWG, Hartley RE, Gundry MF. Failure in retinal detachment surgery. Br J Ophthalmol 1973;57:525-30.

4 Lean JS, Mahmood M, Manna R, Chignell AH. Effect of preoperative posture and binocular occlusion on retinal detachment. BrJ Ophthalmol 1980;64:94-7.

5 Hoffman H, Hanselmayer H. Retinal detachment-extent and frequency of reattachment through preoperative immobilisation. Klin Monatsbl Augenheilkol 1973;162:178-85.

6 Johnston PB, Maguire CJF, Logan WC. Management of superior-half bullous retinal detachment. Br J Ophthalmol 1981;65:618-22.

7 Algvere P, Rosengren B. Immobilisation of the eye. Acta Ophthalmol (Kbh) 1977;55:303-16.

8 Fineberg E, Machemer R, Sullivan P, Norton EWD, Hamasaki $D$, Anderson D. Sulfur hexafluoride in owl monkey vitreous cavity. Am J Ophthalmol 1975;79:67-76.

9 Chignell AH, Clemett RS, Revie IHS. Pigment fallout and uveitis after cryotherapy. Br J Ophthalmol 1973;57:156-65.

10 Shea M. Complications of cryotherapy in retinal detachment surgery. Can J Ophthalmol 1968;3:109-15.

11 Laqua $H$, Machemer R. Repair and adhesion mechanisms of the cryotherapy lesion in experimental retinal detachment. Am J Ophthalmol 1976;81:833-46.

$12 \mathrm{Ohm}$ J. Ueber die Behandlung der Netzhautablösung durch operative Entleerung der subretinalen Flüssigkeit und Einspritzung von luft in den Glaskörper. Graefes Arch Klin Exp Ophthalmol 1911;79:442-50.

13 Rosengren B. Cases of retinal detachment treated with diathermy and injection of air into the vitreous body. Acta Ophthalmol (Kbh) 1938;16:573-9. 
14 Rosengren B. 300 cases operated on for retinal detachments. Acta Ophthalmol (Kbh) 1952;30:117-22.

15 Norton EWD. Intraocular gas in the management of selected retinal detachments. Ophthalmology (Rochester) 1973;77:85-98.
16 Chawla HB, Birchall CH. Intravitreal air in retinal detachment surgery. Br J Ophthalmol 1973;57:60-70.

17 Chawla HB. Intravitreal air in aphakic retinal detachment. Br J Ophthalmol 1973;57:58-60. 